\title{
TANGGUNG JAWAB JABATAN DAN TANGGUNG JAWAB PRIBADI DALAM PENGGUNAAN DISKRESI SEBAGAI INSTRUMEN PELAYANAN PUBLIK (PUBLIC SERVICE)
}

\author{
Adam Setiawan* dan Nehru Asyikin** \\ Dosen Fakultas Hukum Universitas 17 Agustus 1945 Samarinda \\ J1. Ir. H. Juanda, No.80 Universitas 17 Agustus 1945, Air Hitam, Samarinda, Kalimantan Timur \\ Direktur Lembaga Bantuan Hukum Aksa Bumi Yogyakarta \\ Jl. Sidikan No.62, Sorosutan, Kec. Umbulharjo, Kota Yogyakarta, Daerah Istimewa Yogyakarta 555162 \\ Abstract \\ Discretion is part of the authority to act freely by government officials to ensure the implementation of \\ public services. The instrument of discretion is attached to the functionary and used to overcome problems \\ where there is no law. But sometimes the use of discretion causes harm to the community, so it is important \\ to know the form of official responsibility whether it is functionary responsibility or personal responsibility. \\ Government officials who use discretion, as long as the action is carried out within the formal environment \\ of their authority or carried out in the context of exercising office authority, all consequences that arise \\ will be the responsibility of the functionary. While personal responsibility is related to maladministration \\ in the use of authority and public service.
}

Keywords: discretion, functionary responsibility, personal responsibility.

\section{Intisari}

Diskresi merupakan bagian dari kewenangan bertindak bebas oleh pejabat pemerintah untuk menjamin terlaksananya pelayanan publik. Instrumen diskresi melekat pada jabatan dan dipergunakan untuk mengatasi persoalan yang tidak ada hukumnya. Namun terkadang penggunaan diskresi menyebabkan kerugian bagi masyarakat sehingga penting mengetahui bentuk tanggung jawab pejabat apakah itu tanggung jawab jabatan atau tanggung jawab pribadi. Pejabat pemerintah yang menggunakan diskresi, selama tindakan itu dilakukan dalam lingkungan formil wewenangnya atau dilakukan dalam rangka melaksanakan kewenangan jabatan, semua konsekuensi yang timbul akan jadi tanggung jawab jabatan. Sedangkan tanggung jawab pribadi berkaitan dengan maladministrasi dalam penggunaan wewenang maupun public service.

Kata kunci : diskresi, tanggung jawab jabatan, tanggung jawab pribadi.

\section{Pokok Muatan}

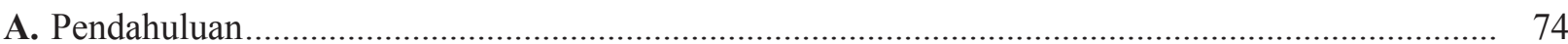

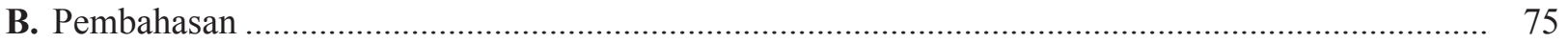

1. Diskresi Sebagai Instrumen Pelayanan Publik (Public Service) .................................................. 75

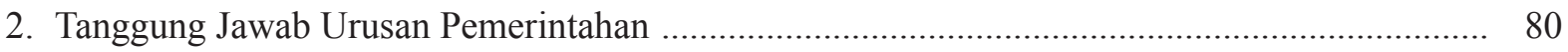

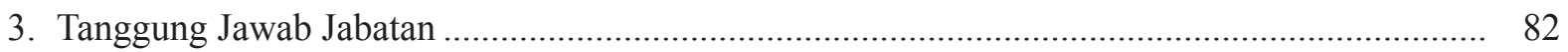

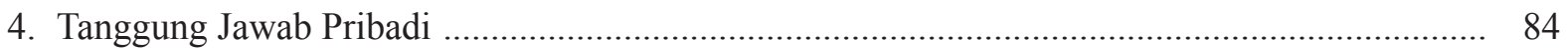

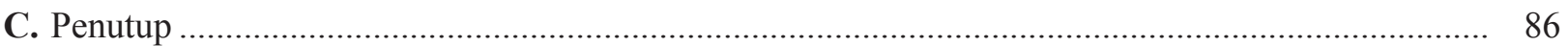

Alamat Korespodensi: adamsetiawanmunif@gmail.com.

Alamat Korespodensi: nehruasyikin1@gmail.com. 


\section{A. Pendahuluan}

Peran negara yang utama dalam suatu negara adalah mewujudkan cita-cita dari bangsa itu sendiri seperti yang termaktub di setiap konstitusi atau Undang-Undang Dasar Negara yang bersangkutan. Salah satu tujuan negara bagi Indonesia adalah untuk memajukan kesejahteraan warga negara Indonesia dan membentuk negara kesejahteraan, sebagaimana yang sudah disebutkan di dalam Pembukaan ke IV yang bunyinya: Alinea ke keempat

“....membentuk suatu Pemerintah Negara Indonesia yang melindungi segenap bangsa Indonesia... untuk memajukan kesejahteraan umum, mencerdaskan kehidupan bangsa, dan ikut melaksanakan ketertiban dunia yang berdasarkan kemerdekaan, perdamaian abadi, dan keadilan sosial...”.

Sebagai Negara yang bertujuan untuk memajukan kesejahteraan umum, melekatnya fungsi memajukan kesejahteraan umum dalam welfare state (Negara kesejahteraan) menimbulkan beberapa konsekuensi terhadap penyelenggaraan pemerintahan yaitu pemerintah harus berperan aktif mencampuri bidang kehidupan sosial ekonomi masyarakat. ${ }^{1}$

Paradigma negara kesejahteraan muncul sebagai reaksi atas kegagalan konsep legal state atau negara penjaga malam (nachtwakerstaat). Dalam konsepsi legal state terdapat prinsip staatsonthouding atau pembatasan peranan negara dan pemerintah dalam bidang politik yang bertumpu pada dalil "The least goverment is the best goverment", dan terdapat prinsip "laissez faire, laissez aller" dalam bidang ekonomi yang melarang negara dan pemerintah mencampuri kehidupan ekonomi masyarakat (staatsbemoeienis). ${ }^{2}$ Kegagalan implementasi nachtwachtersstaat tersebut kemudian muncul gagasan yang menempatkan pemerintah sebagai pihak yang bertanggung jawab atas kesejahteraan rakyatnya, yaitu welfare state. ${ }^{3}$ Pemerintah dilimpahkan tanggung jawab bestuurszorg atau public service untuk merealiasasi konsep negara kesejahteraan (negara hukum modern).

Implementasi pelayanan publik (public service), pemerintah sebagai pelaksana aktivitas pelayanan publik setiap harinya, harus melakukan aktivitas pelayanan publik berdasarkan hukum tertulis sebagaimana asas legalitas yang dianut. Selaras dengan L.J.A. Damen yang menyatakan bahwa dalam suatu negara hukum, keterlibatan pemerintah dalam kehidupan warga negara itu harus didasarkan pada asas legalitas (legaliteitsbeginsel), yang dianggap sebagai dasar terpenting negara hukum. ${ }^{4}$ Akan tetapi, kelemahan asas legalitas yang lebih bermakna pada hukum tertulis menyimpan banyak persoalan, sebagaimana layaknya di negara Indonesia. Phipus M. Hadjon menyatakan ide rechstaat cenderung ke arah positivisme hukum yang membawa konsekuensi bahwa hukum harus dibentuk secara sadar oleh badan pembentuk perundang-undangan. ${ }^{5}$

Terkait persoalan pelayanan publik yang dalam dinamikanya selalu mengikuti alur kebutuhan warga negara yang sifatnya dinamis (flexible). Pemerintah acapkali dibuat kewalahan, tatkala penyelenggaraan pelayanan publik hanya berpedoman pada peraturan perundang-undangan (wetgeving) sehingga menimbulkan ambivalensi tindakan pemerintahan. S.F Marbun di dalam disertasinya menyatakan bahwa servis publik dapat dilaksanakan dan mencapai hasil maksimal, kepada administrasi negara diberikan suatu kemerdekaan tertentu untuk bertindak atas inisiatif sendiri menyelesaikan berbagai permasalahan pelik yang membutuhkan penanganan secara cepat. ${ }^{6}$ Sementara terhadap permasalahan itu tidak ada,

\footnotetext{
Julista Mustamu, "Diskresi dan Tanggung Jawab Administrasi Pemerintahan”, Jurnal Sasi, Vol. 17, No. 2, April-Juni 2011 , hlm. 1.

Ridwan, 2017, Hukum Administrasi Negara, Rajawali Press, Jakarta, hlm. 14.

Ibid.

Ridwan, 2014, Diskresi dan Tanggung Jawab Pemerintah, FH UII Press, Yogyakarta, hlm. 4.

Ibid, hlm. 5 .

S.F. Marbun, 2001, Pembentukan, Pemberlakuan, dan Peranan Asas-Asas Umum Pemerintahan yang Layak dalam Menjelmakan Pemerintahan yang Baik dan Bersih di Indonesia, Disertasi Program Doktor Fakultas Hukum Universitas Padjajaran, Bandung, hlm. 17.
} 
atau masih belum dibentuk suatu dasar hukum penyelesaiannya oleh lembaga legislatif yang kemudian dalam hukum administrasi diberikan kewenangan bebas berupa diskresi. ${ }^{7}$

Ridwan menegaskan bahwa terhadap persoalan urusan yang belum ada pengaturannya (leemten in het recht), sementara harus dilayani oleh pemerintah, maka dalam rangka pelayanan terhadap warga negara organ pemerintah menggunakan diskresi. Adapun terhadap persoalan yang ada peraturannya, penggunaan diskresi juga dimungkinkan terutama berkenaan dengan norma samar (vage norm) atau norma terbuka (open texture) yang terdapat dalam peraturan perundangperundang tersebut sehingga memerlukan penjelasan, interpretasi, pertimbangan berbagai kepentingan terkait, atau karena dalam peraturan itu terdapat pilihan yang dapat diambil oleh organ pemerintah dalam melaksanakan tugas-tugasnya. ${ }^{8}$

Penggunaan diskresi oleh pemerintah sebagai instrumen untuk mengatur jalannya pelayanan publik (public service) terhadap warga negara, terkadang ada kalanya diskresi tersebut merugikan kepentingan warga negara baik secara langsung maupun tidak langsung. Sebagai contoh diskresi yang dilakukan oleh Menteri Kesehatan dengan alasan keterbatasan waktu, kejadian luar biasa (KLB) dalam bentuk konsep verbal Menkes/ XI/2005 dan No 15911/Menkes/XI/2005, dengan ini terbitlah surat rekomendasi permohonan terhadap pengadaan barang dengan penunjukan langsung pembuatan vaksin flu burung, yang menyebabkan negara mengalami kerugian sebesar sekitar $\mathrm{Rp}$ 6 miliar. Atas dasar kerugian tersebut, penting rasanya mengetahui bentuk tanggung jawab dari pengguna diskresi.

Contoh berikutnya adalah terkait dengan terbitnya Peraturan Gubernur Daerah Khusus Ibukota Jakarta Nomor 187 Tahun 2017 tentang Tim Gubernur untuk Percepatan Pembangunan. Menjadi titik permasalahan adalah terkait penganggaran gaji dimana harus menyesuaikan Peraturan Presiden Nomor 4 Tahun 2015 tentang Perubahan Keempat Atas Peraturan Presiden Nomor 54 Tahun 2010 tentang Pengadaan Barang/Jasa Pemerinta ${ }^{9}$ karena proses pengadaan tenaga ahli itu sama dengan proses pengadaan barang pemerintah, dia disebut jasa. Apabila tidak melakukan proses sesuai perundangan, ini merupakan pelanggaran Peraturan Presiden Nomor 4 Tahun 2015 hanya mengizinkan penunjukan langsung pada pengadaan jasa konsultasi yang bernilai paling tinggi $\mathrm{Rp} 50$ juta. Dalam perencanaan Pemprov DKI, gaji paling tinggi didapatkan oleh Ketua Tim Gubernur Untuk Percepatan Pembangunan (selanjutnya disebut TGUPP), yakni Rp 51,5 juta. Sementara gaji para ketua bidang dan puluhan anggota TGUPP lainnya berada di bawah Rp 50 juta. Jika dikaji secara cermat ada perbedaan yang signifikan antara kebijakan yang diterbitkan oleh Gubernur DKI Jakarta dengan Peraturan Presiden. Sehingga perlu dielaborasi bentuk tanggung jawab dari Gubernur DKI Jakarta. Berdasarkan beberapa contoh yang telah disebutkan menarik untuk ditelusuri secara komprehensif mengenai bentuk tanggung jawab jabatan dan tanggung jawab pribadi dalam penggunaan diskresi sebagai instrumen pelayanan publik (public service).

\section{B. Pembahasan \\ 1. Diskresi Sebagai Instrumen Pelayanan Publik (Public Service)}

Persoalan mengenai pelayanan publik di Indonesia merupakan keharusan manakala seorang pejabat diberikan mandat oleh undang-undang untuk melakukan pelayanan yang terbaik kepada masyarakat sebagai aspek dasar dibentuknya sebuah pemerintahan.

Persoalan pelayanan publik yang dalam dinamikanya selalu mengikuti alur kebutuhan warga 
negara yang sifatnya dinamis (flexible). Pemerintah acapkali dibuat kewalahan, tatkala penyelenggaraan pelayanan publik hanya berpedoman pada peraturan perundang-undangan (wetgeving) sehingga menimbulkan ambivalensi keputusan/tindakan pemerintahan. Terhadap persoalan urusan yang belum ada pengaturannya (leemten in het recht), sementara harus dilayani oleh pemerintah, maka dalam rangka pelayanan terhadap warga negara organ pemerintah menggunakan diskresi. ${ }^{10}$

Adapun diskresi sebagai instrumen pelayanan publik dalam hal ini berkorelasi pada kinerja pemerintah dalam menjalankan penyelenggaraan negara. Selaras dengan pendapat M. Ryaas Rasyid yang mengatakan bahwa pemerintahan pada hakikatnya adalah pelayanan kepada masyarakat. Pemerintah tidak diadakan untuk melayani dirinya sendiri, akan tetapi untuk melayani masyarakat dan menciptakan kondisi yang memungkinkan setiap anggota masyarakat mengembangkan kemampuan dan kreativitasnya untuk mencapai tujuan bersama. ${ }^{11}$ Definisi dari pelayanan publik menurut Boediono adalah bahwa pelayanan merupakan suatu proses bantuan kepada orang lain dengan cara-cara tertentu yang memerlukan kepekaan dan hubungan interpersonal agar terciptanya kepuasan dan keberhasilan. ${ }^{12}$ Selain itu menurut Agus Dwiyanto, pelayanan publik adalah ranah dimana berbagai aspek good governance dapat diartikulasikan secara relatif lebih mudah. Aspek yang selama ini sering dijadikan rujukan dalam menilai praktik governance dapat dengan mudah dinilai dalam praktik penyelenggaraan pelayanan publik. $^{13}$

Pelayanan publik atau pelayanan umum dapat didefinisikan sebagai segala bentuk jasa pelayanan, baik dalam bentuk barang publik maupun jasa publik yang pada prinsipnya menjadi tanggung jawab dan dilaksanakan oleh instansi pemerintah di pusat, di daerah, dan di lingkungan Badan Usaha Milik Negara atau Badan Usaha Milik Daerah, dalam rangka upaya pemenuhan kebutuhan masyarakat maupun dalam rangka pelaksanaan ketentuan peraturan perundang undangan. Karenanya birokrasi publik berkewajiban dan bertanggung jawab untuk memberikan pelayanan yang baik dan profesional. ${ }^{14}$ Menurut Gie pelayanan merupakan suatu kegiatan dalam suatu organisasi atau instansi yang dilakukan untuk mengamalkan dan mengabdikan diri kepada masyarakat. ${ }^{15}$ Lijan Poltak Sinambela memaknai pelayanan publik sebagai pemenuhan keinginan dan kebutuhan masyarakat oleh penyelenggara negara. Negara didirikan oleh publik (masyarakat) tentu saja dengan tujuan agar dapat meningkatkan kesejahteraan masyarakat. ${ }^{16}$

Berdasarkan Undang-Undang Nomor 25 Tahun 2009 tentang Pelayanan Publik, Pasal 1 ayat (1) Pelayanan publik adalah kegiatan atau rangkaian kegiatan dalam rangka pemenuhan kebutuhan pelayanan sesuai dengan peraturan perundangundangan bagi setiap warga negara dan penduduk atas barang, jasa, dan/atau pelayanan administratif yang disediakan oleh penyelenggara pelayanan publik.

Adapun pendapat para ahli dan definisi Undang-Undang Nomor 25 Tahun 2009 tentang Pelayanan Publik yang dikemukakan di atas, dapat ditarik inti dari pengertian pelayanan publik yaitu suatu bentuk layanan yang diberikan pemerintah, non pemerintah, seperti swasta atau masyarakat untuk memenuhi kebutuhan hidup masyarakatnya. Selain itu penyelenggaraan pelayanan publik juga harus berlandaskan peraturan perundang-undangan yang berlaku sehingga dapat menjadi acuan dalam

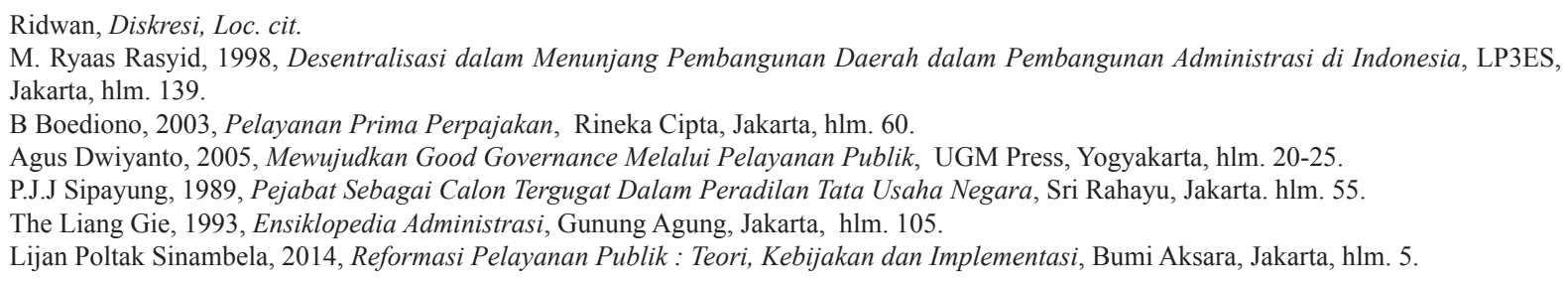


penyelenggarannya.

Implementasi penyelenggaraan pelayanan publik yang seharusnya (sollen) selaras dengan tujuannya yaitu meningkatkan kualitas hidup masyarakat (quality of life) dalam hal ini memberikan kesejahteraan (welfare) kepada seluruh rakyat Indonesia. Namun pada kenyataannya (sein) pelayanan publik sering mendapatkan banyak kendala, dikarenakan regulasi yang mengatur tidak ada (rechtvacuum). Bagir Manan mengingatkan bahwa peraturan perundang-undangan juga mengandung masalah-masalah antara lain: Pertama, peraturan perundang-undangan tidak flexible. Tidak mudah menyesuaikan peraturan perundangundangan dengan perkembangan masyarakat; Kedua, peraturan perundang-perundangan tidak pernah lengkap untuk memenuhi semua peristiwa hukum atau tuntutan hukum dan ini yang akan menimbulkan apa yang lazim disebut dengan kekosongan hukum (peraturan). ${ }^{17}$

Dengan adanya instrumen diskresi yang diberikan terhadap pemerintah sebagai penyelenggara pelayanan publik sudah sangatlah tepat, karena mampu mengikuti perkembangan zaman dan kebutuhan masyarakat yang sangat dinamis. Selaras dengan hal tersebut Sajchran Basan ${ }^{18}$ menyatakan bahwa tugas servis publik itu membawa administrasi negara kepada suatu konsekuensi khusus yaitu memerlukan "pouivoir discretionnaire" untuk dapat bertindak inisiatip sendiri. Hal itu terdapat terutama dalam penyelesaian persoalan-persoalan penting yang timbul secara dan tumbuh secara tiba-tiba.

Terminologi diskresi di berbagai negara memiliki tata bahasa yang berbeda-beda antara lain: Diskresi atau discretion (Inggris) atau discre'tion (Prancis), atau Freies Ermessen (Jerman). Dalam kamus hukum kontemporer (The Contemporary Law Dictionary) istilah Discretion memiliki arti kebijaksanaan, hikmat, suatu keputusan pimpinan atas dasar hikmat suatu keputusan pimpinan atas dasar hikmat dan hati nurani. ${ }^{19}$ Istilah Descre tion (Perancis) berarti kebijaksanaan, keleluasaan, kehati-hatian atau descre'tionnaire (kata sifat), yang berarti menyerahkan kepada kebijaksanaan dengan kebebasan untuk menentukan atau memilih. ${ }^{20}$

Lebih lanjut istilah freies Ermessen bersumber dari lingkungan (literatur) hukum administrasi Jerman. Secara etimologis dalam bahasa Jerman kata freise Ermessen terdiri dari dua suku kata Freie dan Ermessen. Kata freise berasal dari kata Freie artinya bebas, bebas, merdeka dan tidak terikat, sedangkan kata freies berarti orang bebas. Adapun kata Ermessen mengandung arti mempertimbangkan, menilai, menduga dan memutuskan. ${ }^{21}$ Menurut sistem administrasi Jerman freise Ermessen merupakan bagian dari administrasi yang memberikan ruang gerak bagi administrasi negara untuk melakukan tindakan tanpa harus terkait sepenuhnya undang-undang. ${ }^{22}$

Diana Halim Koentjoro mengartikan freies ermessen sebagai kemerdekaan bertindak administrasi negara atau pemerintah (eksekutif) untuk menyelesaikan masalah yang timbul dalam keadaan kegentingan yang memaksa, di mana peraturan penyelesaian untuk masalah itu belum ada. Sedangkan Esmi Warassih mengatakan bahwa dalam rangka pelaksanaan kebijaksanaan publik, para birokrat dapat menentukan kebijaksanaannya sendiri untuk menyesuaikan dengan situasi dimana mereka berada, terutama di dalam mengimplementasikan suatu kebijaksanaan publik. Dengan adanya diskresi ini diharapkan agar dengan kondisi yang ada dapat dicapai suatu hasil atau tujuan yang maksimal. ${ }^{23}$ Pendapat ahli lainnya seperti Ridwan HR memaknai diskresi sebagai pertimbangan sendiri, wewenang untuk

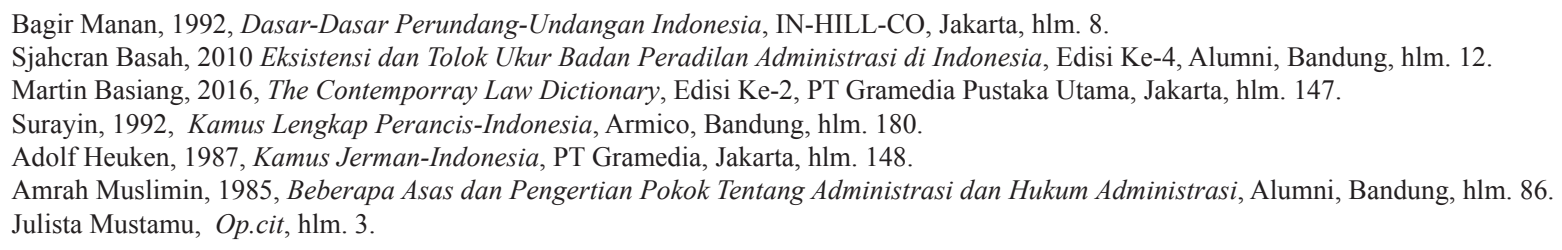


melakukan tindakan berdasarkan kebijakan sendiri, pertimbangan seorang pejabat publik dalam melaksanakan tugasnya dan kekuasaan seseorang untuk mengambil pilihan melakukan atau tidak melakukan tindakan. ${ }^{24}$

Selaras dengan apa yang dikemukakan oleh Ridwan HR, H.D van Wijk/Willem Konijnenbelt mengemukakan bahwa diskresi merupakan kebebasan organ pemerintah untuk mengambil pilihan dan melakukan atau tidak melakukan tindakan memunculkan dua macam kebebasan yakni kebebasan mengambil kebijakan (beleidsvrijheid) dankebebasan mempertimbangkan (beoordelingsvrijheid). ${ }^{25}$ Berdasarkan beberapa pengertian yang telah dikemukakan, penulis berasumsi bahwa diskresi merupakan kewenangan bertindak bebas (authority) yang dimiliki oleh pejabat publik dalam lingkup melaksanakan aktivitas pemerintah.

Berdasakan Pasal 1 ayat 9 Undang-Undang Nomor 30 Tahun 2014 tentang Administrasi Pemerintahan (selanjutnya disebut UU Adpem), diskresi adalah Keputusan dan/atau Tindakan yang ditetapkan dan/atau dilakukan oleh Pejabat Pemerintahan untuk mengatasi persoalan konkret yang dihadapi dalam penyelenggaraan pemerintahan dalam hal peraturan perundang-undangan yang memberikan pilihan, tidak mengatur, tidak lengkap atau tidak jelas, dan/atau adanya stagnasi pemerintahan. Berdasarkan rumusan pengertian tersebut terdapat unsur-unsur Diskresi, adalah keputusan dan/atau tindakan, dilakukan oleh Pejabat Pemerintah, untuk mengatasi persoalan konkret yang dihadapi dalam penyelenggaraan pemerintahan, dan dalam hal peraturan perundangundangan yang memberikan pilihan, tidak mengatur, tidak lengkap atau tidak jelas, dan /atau adanya stagnasi pemerintahan.
Sjachran Basah memberikan gambaran mengenai penggunaan diskresi dalam hal penyelenggaraan pelayanan publik: ${ }^{26}$

"Untuk menjalankan tugas-tugas servis publik itu secara aktif, maka bagi administrasi negara timbul konsekuensi khusus, yaitu diperlukan "freies Ermessen" yang dimungkinkan oleh hukum agar dapat bertindak atas inisiatif sendiri. Hal itu terdapat terutama dalam penyelesaian persoalan-persoalan penting yang timbul secara tiba-tiba. Dalam hal demikian, administrasi negara terpaksa bertindak cepat, membuat penyelesaian. Namun keputusan-keputusan yang diambil untuk menyelesaikan masalah-masalah itu, harus dapat dipertanggungjawabkan.”

Adapun gambaran yang telah dikemukakan oleh Sjachran Basah. Timbul pertanyaan siapa saja pihak yang memiliki wewenang untuk menggunakan instrumen diskresi dan keadaan seperti apa diskresi dapat digunakan jika merujuk UU Adpem. Berdasarkan Pasal 22 ayat (1) dan (2) UU Adpem, Pasal 22 ayat (1) menyebutkan bahwa Diskresi hanya dapat dilakukan oleh Pejabat Pemerintahan yang berwenang. Dalam perkembangannya yang dimaksud pejabat berwenang dilihat dari ruang lingkup pengaturan Administrasi Pemerintahan dalam dalam hal ini meliputi semua aktivitas: $:^{27}$

a. Badan dan/atau Pejabat Pemerintahan yang menyelenggarakan Fungsi Pemerintahan dalam lingkup lembaga eksekutif;

b. Badan dan/atau Pejabat Pemerintahan yang menyelenggarakan Fungsi Pemerintahan dalam lingkup lembaga yudikatif;

c. Badan dan/atau Pejabat Pemerintahan yang menyelenggarakan Fungsi Pemerintahan dalam lingkup lembaga legislatif; dan

d. Badan dan/atau Pejabat Pemerintahan lainnya yang menyelenggarakan Fungsi Pemerintahan yang disebutkan

Ridwan, Diskresi dan...Op.cit., hlm. 125

H.D van Wijk/Willem Konijnenbelt, Hoofdstukken van Administratief Recht, dikutip dari Ridwan, Diskresi... Op.cit, hlm. 135.

Sjachran Basah, Op.cit, hlm. 151

Pasal 4 ayat (1) Undang-Undang Nomor 30 Tahun 2014 tentang Administrasi Pemerintah (Lembaran Negara Republik Indnesia Tahun 2014

Nomor 292, Penjelasan Dalam Tambahan Lembaran Negara Republik Indonesia Nomor 5601). 
Undang-Undang Dasar Negara Republik Indonesia Tahun 1945 dan/ atau undang-undang.

Pemberian diskresi kepada pemerintah itu merupakan kemestian dalam suatu negara hukum modern, namun penggunaan diskresi itu bukan tanpa batas. Batasan dalam penggunaan diskresi dan pembuatan kebijakan pemerintah harus merujuk beberapa syarat sebagaimana konstruksi Pasal 1 ayat (9) UU Adpem, yakni untuk mengatasi persoalan konkret yang dihadapi dalam penyelenggaraan pemerintahan. Dalam hal peraturan perundang-undangan yang memberikan pilihan, tidak mengatur, tidak lengkap atau tidak jelas, dan /atau adanya stagnasi pemerintahan. Selanjutnya dielaborasi dalam Pasal 22 ayat (2) UU Adpem bahwa setiap penggunaan Diskresi Pejabat Pemerintahan bertujuan untuk: a. melancarkan penyelenggaraan pemerintahan; b. mengisi kekosongan hukum; c. memberikan kepastian hukum; dan d. mengatasi stagnasi pemerintahan dalam keadaan tertentu guna kemanfaatan dan kepentingan umum.

Dalam penggunaan diskresi pejabat pemerintahan harus memenuhi beberapa syarat sebagaimana disebutkan dalam Pasal 24, bahwa Pejabat Pemerintahan yang menggunakan diskresi harus memenuhi syarat: a. sesuai dengan tujuan Diskresi sebagaimana dimaksud dalam Pasal 22 ayat (2); b. tidak bertentangan dengan ketentuan peraturan perundang-undangan; c. sesuai dengan AUPB; d. berdasarkan alasan-alasan yang objektif; e. tidak menimbulkan Konflik Kepentingan; dan f. dilakukan dengan iktikad baik. ${ }^{28}$

Berdasarkan beberapa uraian pasal yang telah disebutkan di atas ada beberapa kritik terkait konstruksi pasal mengenai diskresi. Pertama, ada perluasan makna pihak yang berwenang menggunakan instrumen diskresi, sebagaimana disebutkan dalam Pasal 4 bukan hanya lingkup eksekutif saja melainkan pula lingkup yudikatif, legislatif dan penyelenggara negara yang menjalankan fungsi pemerintahan disebutkan oleh Undang-Undang Dasar Negara Republik Indonesia 1945. Secara teoritis tentunya pasal a quo bertentangan dengan esensi diskresi yang dipahami, sebagaimana telah dikemukakan oleh Sjachran Basah bahwa diskresi dipergunakan untuk menjalankan tugas-tugas servis publik itu secara aktif. Laica Marzuki berpendapat bahwa diskresi merupakan kebebasan yang diberikan kepada tata usaha negara dalam rangka penyelenggaraan pemerintahan, sejalan dengan meningkatnya tuntutan pelayanan publik. ${ }^{29}$ Dengan demikian secara konseptual diskresi hanya dapat dipergunakan oleh lingkup administrasi atau eksekutif.

Kedua, definisi diskresi berdasarkan Pasal 1 ayat (9) UU Adpem menyebutkan diskresi adalah Keputusan dan/atau Tindakan yang ditetapkan dan/ atau dilakukan oleh Pejabat Pemerintahan untuk mengatasi persoalan konkret yang dihadapi dalam penyelenggaraan pemerintahan dalam hal peraturan perundang-undangan yang memberikan pilihan, tidak mengatur, tidak lengkap atau tidak jelas, dan/ atau adanya stagnasi pemerintahan. Berdasarkan pasal a quo, perlu digaris tebal terkait frasa keputusan dan/atau tindakan yang menimbulkan kerancuan dalam memahami makna diskresi. Menurut Ridwan $\mathrm{HR}^{30}$, tindakan adalah genus dari semua keputusan yang dikeluarkan oleh pejabat negara baik dalam bentuk regelling, beshicking, izin dan lain sebagainya. Maka apakah yang dimaksud dengan tindakan ini adalah termasuk semua keputusan itu atau tidak? Lalu mengapa menggunakan frasa "keputusan dan/atau tindakan", sementara adalah bagian dari tindakan itu sendiri.

\footnotetext{
28 Undang-Undang Nomor 30 Tahun 2014 tentang Administrasi Pemerintah (Lembaran Negara Republik Indonesia Tahun 2014 Nomor 292 , Tambahan Lembaran Negara Republik Indonesia Nomor 5601).

29 Laica Marzuki, "Peraturan Kebijaksanaan (Beleidsregel) Hakikat serta Fungsinya Selaku Sarana Hukum Pemerintahan”, Makalah, Penataran Nasional Hukum Acara dan Hukum Administrasi Negara, Fakultas Hukum Universitas Hasanudin, Ujung Pandang, 26-31 Agustus 1996, hlm. 7.

30 Ridwan HR, et.al, 2018, Perluasan Kompetensi Absolut PTUN, Total Media, Yogyakarta, hlm. 178.
} 
Ketiga, kerancuan perihal penggunaan diskresi harus mendapatkan persetujuan atasan dan memberitahukan kepada atasan sebagaimana disebutkan dalam Pasal 25 ayat (1) bahwa penggunaan Diskresi yang berpotensi mengubah alokasi anggaran wajib memperoleh persetujuan dari Atasan Pejabat sesuai dengan ketentuan peraturan perundang-undangan. Lalu Pasal 25 ayat (3) Dalam hal penggunaan Diskresi menimbulkan keresahan masyarakat, keadaan darurat, mendesak dan/atau terjadi bencana alam, Pejabat Pemerintahan wajib memberitahukan kepada Atasan Pejabat sebelum penggunaan Diskresi dan melaporkan kepada Atasan Pejabat setelah penggunaan Diskresi. Berdasarkan konstruksi pasal a quo tentunya menimbulkan penolakan keras dari kalangan ahli Hukum Administrasi, seperti kita ketahui diskresi merupakan kewenangan bebas administrasi atas inisiatif sendiri.

Menurut Ridwan HR keharusan untuk mendapatkan persetujuan dari atasan ini menghilangkan makna diskresi. Dalam hal ini, Bupati adalah pemerintahan yang menjalankan fungsi otonomi yang memperoleh kepercayaan langung dari rakyat, tentu menjadi tidak logis jika untuk mengeluarkan kebijakan harus mendapat persetujuan dari Gubernur dulu. Begitu juga halnya dengan Gubernur yang harus mendapat persetujuan dari Presiden sebagai atasannya. Lalu pertanyaan lainnya bagaimana dengan Presiden? Kepada siapa dia harus meminta persetujuan? Apakah jika Presiden mengeluarkan diskresi dianggap tidak sah karena tidak memenuhi unsur ini. Kesulitan lain adalah kondisi geografis Indonesia yang begitu luas namun teknologi masih sangat terbatas, dapat dibayangkan misalnya suatu daerah yang jauh dari pusat terkena bencana alam, dan pejabat pemerintah harus mendapat izin terlebih dahulu dari pusat untuk mengambil kebijakan sementara kebutuhan mendesak untuk segera mendapat bantuan. ${ }^{31}$

\section{Tanggung Jawab Urusan Pemerintahan}

Sebelum mengetahui siapa yang bertanggung jawab dalam penyelenggaraan tugas/urusan pemerintahan dan pelayanan kepada masyarakat, terlebih dahulu perlu dikemukakan tentang jabatan pemerintahan yang dilekati fungsi dan kewenangan pemerintahan. Dalam hukum publik, dikenal istilah pemerintah dan pemerintahan. Pemerintahan adalah bestuurvoering atau pelaksanaan tugas pemerintah. ${ }^{32}$ Philipus M. Hadjon memaknai pemerintahan melalui dua pengertian: di satu pihak dalam arti "fungsi pemerintahan" (kegiatan memeintah), di lain pihak dalam arti "organisasi pemerintahan" (kumpulan dari kesatuan-kesatuan pemerintahan). ${ }^{33}$ Sedangkan istilah pemerintah dibagi menjadi dua yaitu, pemerintah dalam arti sempit dan pemerintah dalam arti luas. Pemerintah dalam arti sempit adalah organ/alat perlengkapan negara yang diserahi tugas pemerintahan atau melaksanakan undang-undang. Dalam pengertian ini pemerintah hanya hanya berfungsi sebagai badan eksekutif (eksekutif atau bestuur). Pemerintah dalam arti luas adalah semua badan yang menyelenggarakan semua kekuasaan di dalam negara kekuasaan eksekutif maupun legislatif dan yudikatif. ${ }^{34}$

Terkait pelaksana pemerintahan, dalam hal ini eksekutif sebagai pemegang fungsi administrasi memiliki urusan/tugas sebagaimana disebutkan dalam. Berdasarkan Pasal 1 ayat(5) Undang-Undang Nomor 23 Tahun 2014 tentang Pemerintah Daerah istilah Urusan Pemerintahan adalah kekuasaan pemerintahan yang menjadi kewenangan Presiden yang pelaksanaannya dilakukan oleh kementerian negara dan penyelenggara Pemerintahan Daerah untuk melindungi, melayani, memberdayakan, dan menyejahterakan masyarakat.

Istilah urusan pemerintahan yang telah disebutkan, dapat dipahami adanya pemencaran kekuasaan secara vertikal (verticale spreiding van machten). Pemencaran kekuasaan (urusan peme-

\footnotetext{
Ridwan HR, Perluasan Kompetensi..., Loc. cit.

M. Nata Saputra, 1988, Hukum Administrasi Negara, Rajawali, Jakarta, hlm. 4.

Philipus M. Hadjon, et al., 2005, Pengantar Hukum Administrasi Indonesia, Introduction to the Indonesian Administrative Law, Edisi Ke-9, Gajah Mada University Press, Yogyakarta, hlm. 6.

34 S F Marbun, et al., 2011, Pokok-Pokok Hukum Administrasi Negara, Edisi Ke-6, Liberty Press, Yogyakarta, hlm. 8.
} 
rintahan) dijalankan berdasarkan desentralisasi, yaitu suatu proses pelimpahan kewenangan dari pusat ke daerah untuk melaksanakan urusan rumah tangganya secara mandiri. Selaras dengan apa yang dikatakan Bagir Manan bahwa desentralisasi adalah pembagian wewenang, tugas dan tanggung jawab antara badan-badan kenegaraan yaitu antara negara dan satuan pemerintahan daerah lebih rendah yang sama-sama sebagai badan publik. ${ }^{35}$

Berdasarkan Pasal 18 ayat (2) UndangUndang Dasar Negara Republik Indonesia 1945, Pemerintah daerah provinsi, daerah kabupaten dan kota mengatur dan mengurus sendiri urusan pemerintahan menurut asas otonomi dan tugas pembantuan. ${ }^{36}$ Asas otonomi berdasarkan Pasal 1 ayat (7) Undang-Undang Nomor 23 Tahun 2014 tentang Pemerintah Daerah adalah prinsip dasar penyelenggaraan Pemerintahan Daerah berdasarkan Otonomi Daerah. Lebih lanjut Berdasarkan Pasal 1 ayat (11) yang dimaksud dengan tugas pembantuan (madebewind) adalah penugasan dari Pemerintah Pusat kepada daerah otonom untuk melaksanakan sebagian Urusan Pemerintahan yang menjadi kewenangan Pemerintah Pusat atau dari Pemerintah Daerah provinsi kepada Daerah kabupaten/kota untuk melaksanakan sebagian Urusan Pemerintahan yang menjadi kewenangan Daerah provinsi. ${ }^{37}$

Berdasarkan Pasal 9 ayat (1) Undang-Undang Pemerintah Daerah, menyebutkan bahwa Urusan Pemerintahan terdiri atas urusan pemerintahan absolut, urusan pemerintahan konkuren, dan urusan pemerintahan umum. Pasal 9 ayat (2) Urusan pemerintahan absolut sebagaimana dimaksud pada ayat (1) adalah Urusan Pemerintahan yang sepenuhnya menjadi kewenangan Pemerintah Pusat. Pasal 9 ayat (3) Urusan pemerintahan konkuren sebagaimana dimaksud pada ayat (1) adalah Urusan Pemerintahan yang dibagi antara
Pemerintah Pusat dan Daerah provinsi dan Daerah kabupaten/kota. Pasal 9 ayat (4) Urusan pemerintahan konkuren yang diserahkan ke Daerah menjadi dasar pelaksanaan Otonomi Daerah. Pasal 9 ayat (5) Urusan pemerintahan umum sebagaimana dimaksud pada ayat (1) adalah Urusan Pemerintahan yang menjadi kewenangan Presiden sebagai kepala pemerintahan. ${ }^{38}$

Adapun pasal-pasal yang telah diuraikan terkait pembagian urusan pemerintahan antara pemerintah pusat dan pemerintah daerah. Ridwan HR menyatakan bahwa pembagian fungsi dan urusan pemerintahan itu pada hakikatnya adalah pembagian fungsi, tugas, dan tanggung jawab antara pemerintah pusat dan pemerintah daerah. Hal ini berarti bahwa fungsi pelayanan kepada warga negara juga menjadi tanggung jawab satuan pemerintah daerah. Dengan kata lain, seperti halnya fungsi pelayanan pemerintahan pusat, pemerintah daerah dituntut untuk melayani dan menyelesaikan setiap persoalan tersebut, tidak peduli apakah persoalan itu ditentukan atau tidak dalam peraturan perundang-undangan. Hal ini membawa konsekuensi pemerintah daerah pun dilekati dengan kewenangan diskresi. ${ }^{39}$

Pemerintah pusat dan pemerintah daerah sama-sama melekat kehendak bebas (diskresi) pada jabatannya, dan konsekuensi mengenai pelaksanaan diskresi berada pada jabatannya dalam wilayah pemerintahan yang dimaksud, sedangkan pada wilayah pribadi seorang pejabat melekat padanya tanggung jawab jabatan selama ia diberikan kewenangan oleh peraturan perundang-undangan. Sehingga tanggung jawab pemerintah dilaksanakan untuk melayani masyarakat dan bertanggung jawab pada seluruh warga negara.

Tanggung jawab pemerintah terhadap warga negara atau pihak ketiga dianut oleh hampir semua

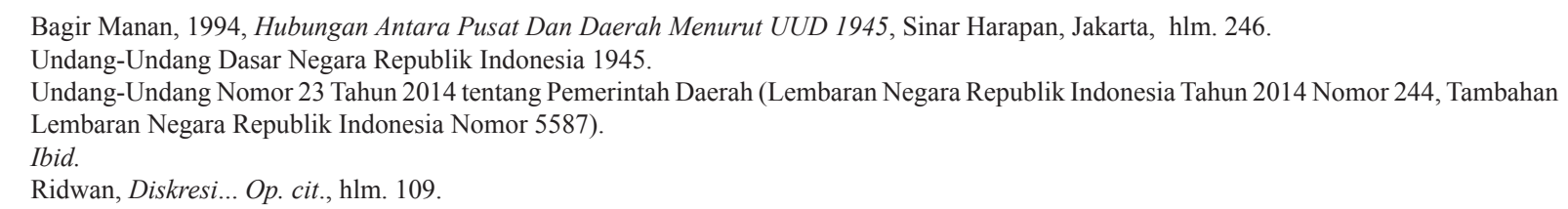


negara yang berdasarkan atas hukum. Sekedar contoh berikut ini dapat disebutkan beberapa negara yang secara tegas memberikan beban tanggng jawab kepada pemerintah, berdasarkan yurisprudensi maupun ketentuan hukum positifnya. Berdasarkan yurisprudensi Conseil d'Etat, pemerintah atau negara dibebani membayar ganti rugi kepada seseorang rakyat atau warga negara yang menjadi korban pelaksanaan tugas administratif. Berdasarkan yurisprudensi yang ditentukan oleh House of Lords Inggris ditentukan bahwa raja atau pemerintah bertanggung jawab atas konsekuensi-konsekuensi yang timbul akibat kelalaian dan kecerobohan pejabat pemerintah dalam menjamin pelaksanaan tugas mereka.

Penggunaan instrumen diskresi yang dilakukan oleh pemerintah maupun penyelenggara negara lain terkait pelayanan publik (bestuurszorg) terkadang mengalami banyak kendala, di antaranya adalah merugikan hak-hak warga negara akibat diskresi yang dipergunakan oleh pemerintah baik berupa keputusan ataupun tindakan. Kerugian yang dialami oleh warga negara akibat penggunaan instrumen diskresi oleh pemerintah dapat dikatakan merupakan penyalahgunaan wewenang (detournement de pouvoir) atau tindakan sewenangwenang pemerintah (willekeur).

Terkait penggunaan diskresi sebagai instrumen penyelenggaraan pelayanan publik yang terkadang dalam implementasinya bisa merugikan hak-hak warga negara akibat penyalahgunaan wewenang (detournement de pouvior) ataupun tindakan sewenang-wenang pemerintah (willekeur). Ridwan HR menjelaskan ada dua entitas yang dapat dibedakan namun tidak dapat dipisahkan yakni jabatan dan pemangku jabatan atau pejabat. Terkait dengan dua entitas itu dikenal adanya dua jenis norma yaitu norma pemerintahan (bestuurnorm) dan norma perilaku aparat (gedragsnorm). Norma pemerintahan adalah kaidah-kaidah hukum tertulis dan tidak tertulis yang berlaku diterapkan terhadap jabatan pemerintahan, sedangkan norma perilaku merupakan kaidah-kaidah hukum tertulis dan tidak tertulis yang harus diperhatikan dan dipatuhi oleh pemangku jabatan. ${ }^{40}$

Lebih lanjut menurut The Liang Gie, setiap petugas administrasi pemerintahan wajib memahami asas-asas etis yang bersumber pada berbagai kebajikan moral, kemudian membina diri sehingga sungguh-sungguh menghayati asas-asas itu, dan terakhir benar-benar menerapkan sebanyak mungkin dalam tindakan jabatannya. Berbagai asas etis yang pokok dalam administrasi pemerintahan ialah: 1) pertanggungjawaban (responsibility); 2) pengabdian (dedication); 3) kesetiaan (loyalty); 4) kepekaan (sensitivity); 5) Persamaan (equality); 6) kepantasan (equity). ${ }^{41}$

Beberapa pendapat yang telah dikemukakan di atas terkait penggunaan diskresi sebagai instrumen pelayanan publik dengan berpedoman pada asas-asas etis, perlu kita elaborasi bagaimana bentuk tanggung jawab jabatan dan tanggung jawab pribadi dalam penggunaan instrument diskresi dalam pelayanan publik (bestuurszorg).

\section{Tanggung Jawab Jabatan}

Definisi dari jabatan di dalam KBBI adalah pekerjaan (tugas) dalam pemerintahan atau organisasi. ${ }^{42}$ Jabatan adalah suatu lembaga dengan lingkup pekerjaan sendiri yang dibentuk untuk waktu lama dan kepadanya diberikan tugas dan wewenang. ${ }^{43}$ Logemann mengatakan:

"Het is dan door ganse staatrecht heen het ambt, waaraan plichten worden opgelegd, dat tot rechtshandelingen wordt bevoegd gemaakt. Plichten en rechten werken door, ongeacht de wisseling der ambtsdragers"

(berdasarkan Hukum Tata Negara, jabatanlah yang

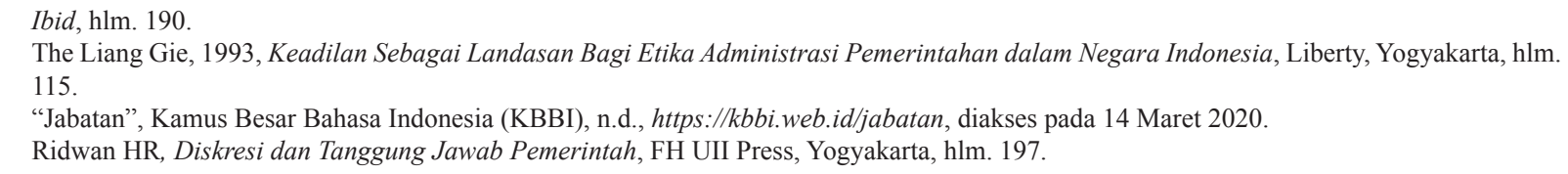


dibebani dengan kewajiban, yang diberi wewenang untuk melakukan perbuatan hukum. Hak dan Kewajiban berjalan terus, tidak peduli dengan pergantian pejabat). Karena kewenangan itu melekat pada jabatan, sementara tanggung jawab dalam bidang publik itu terkait dengan kewenangan, maka beban tanggung jawab itu pada dasarnya juga melekat pada jabatan. ${ }^{44}$

Tanggung jawab jabatan ini berkenan dengan keabsahan tindakan hukum pemerintahan yang dilakukan oleh pejabat untuk dan atas nama jabatan (ambtshalve). Menurut F.R. Bothlingk, baik wakil maupun yang diwakili adalah pelaku, namun tidak berarti bahwa keduanya mempunyai tanggung jawab. Berkenaan dengan perbuatan hukum, jawabannya jelas. Perbuatan hukum adalah pernyataan kehendak dan tanggung jawab secara khusus tertuju kepada pihak yang kehendaknya dinyatakan, yakni pihak yang diwakili. Wakil tidak menyatakan kehendaknya sendiri, karena itu meletakan tanggung jawab kepadanya tidak pada tempatnya.

Terkait dengan kewenangan, diskresi juga merupakan wewenang yakni wewenang bebas (vrij bevoegdheid), diskresi melekat pada jabatan. Sebagai sesuatu yang melekat pada jabatan, penggunaan diskresi itu pada dasarnya adalah dalam rangka melaksanakan kewengan jabatan. Dengan kata lain ketika pejabat pemerintah menggunakan diskresi, ia bertindak untuk dan atas nama jabatan (ambtshalve). Pejabat pemerintah yang menggunakan diskresi, selama tindakan itu dilakukan dalam lingkungan formil wewenangnya (zolang hij tenminste binnen formele kring van zijn bevoegdheid heft gehanded) atau dilakukan dalam rangka melaksanakan kewenangan jabatan, semua konsekuensi yang timbul akan jadi tanggung jawab jabatan. ${ }^{45}$ Bentuk tanggung jawab jabatan dalam penggunaan diskresi dengan bentuk peraturan kebijakan ada kalanya bertentangan dengan asasasas hukum yang berlaku sebagai contoh:

Terbitnya Peraturan Gubernur Daerah Khusus Ibukota Jakarta Nomor 187 Tahun 2017 tentang Tim Gubernur Untuk Percepatan Pembangunan. Terkait peraturan Gubernur yang merupakan bentuk discrecionary power, sebagai pintu terbentuknya sebuah institusi internal yang fungsinya mengawasi proses percepatan pembangunan. ${ }^{46}$ Yang menjadi titik permasalahan adalah pengalokasian anggaran gaji dimana harus menyesuaikan Peraturan Presiden Nomor 4 Tahun 2015 tentang Pengadaan Barang/ Jasa Pemerintah yang merupakan perubahan keempat atas Peraturan Presiden Nomor 54 Tahun 2010 tentang Pengadaan Barang/Jasa Pemerintah. ${ }^{47}$ Karena proses pengadaan tenaga ahli itu sama dengan proses pengadaan barang pemerintah, dia disebut jasa atau dalam Peraturan Presiden Nomor 4 Tahun 2015 disebut dengan Jasa Konsultansi. ${ }^{48}$ Kalau tidak melakukan proses sesuai perundangan, ini merupakan pelanggaran terhadap Perpres Nomor 4 Tahun 2015 yang hanya mengizinkan penunjukan langsung pada pengadaan jasa konsultasi yang bernilai paling tinggi Rp 50 juta. Dalam perencanaan Pemerintan Provinsi DKI, gaji paling tinggi didapatkan oleh Ketua TGUPP, yakni Rp 51,5 juta. Sementara gaji para Ketua Bidang dan puluhan Anggota TGUPP lainnya berada di bawah Rp50 juta. Artinya, pemilihan untuk pengisi jabatan Ketua TGUPP harus melalui proses lelang.

Adapun kebijakan terkait penganggaran gaji TGUPP tersebut jika telaah secara teliti telah terjadi ketidakcermatan dalam membuat kebijakan

\footnotetext{
Ridwan HR, Hukum Administrasi, Op. cit, hlm. 77.

Ridwan HR, Diskresi..., Op. cit, hlm. 200-201.

Peraturan Gubernur Provinsi Daerah Khusus Ibukota Jakarta Nomor 187 Tahun 2017 tentang Tim Gubernur untuk Percepatan Pembangunan (Berita Daerah Provinsi Daerah Khusus Ibukota Jakarta Tahun 2017 Nomor 72109).

47 Peraturan Presiden Republik Indonesia Nomor 4 Tahun 2015 tentang Perubahan Keempat Atas Peraturan Presiden Nomor 54 Tahun 2010 tentang Pengadaan Barang / Jasa Pemerintah (Lembaran Negara Republik Indonesia Tahun 2015 Nomor 5).

48 Jasa Konsultansi adalah jasa layanan profesional yang membutuhkan keahlian tertentu diberbagai bidang keilmuan yang mengutamakan adanya olah pikir (brainware), Pasal 1 ayat (16) Peraturan Gubernur Provinsi Daerah Khusus Ibukota Jakarta Nomor 187 Tahun 2017 tentang Tim Gubernur untuk Percepatan Pembangunan (Berita Daerah Provinsi Daerah Khusus Ibukota Jakarta Tahun 2017 Nomor 72109 ).
} 
(make decision) oleh Pemerintah Provinsi DKI Jakart c.q Gubernur DKI Jakarta karena tidak merujuk pada Peraturan Presiden yang mengatur mengenai proses pengadaan barang/jasa. Secara eksplisit telah disebutkan dalam Pasal 129 bahwa Pengaturan Pengadaan Barang/Jasa yang dibiayai APBD, apabila ditindaklanjuti dengan Peraturan Daerah/Keputusan Kepala Daerah/Pimpinan Institusi Pengguna APBD, harus tetap berpedoman serta tidak boleh bertentangan dengan ketentuan Peraturan Presiden ini.

Dengan demikian berdasarkan peraturan kebijakan (beleidsregel) yang diterbitkan oleh Gubernur DKI tidak bisa take it for granted untuk langsung diimplementasikan, karena telah bertentangan dengan beberapa asas yang merupakan lingkup AAUPB diantaranya asas kepastian hukum dan asas kecermatan.

Sudah seyogyanya Pejabat Pemerintahan yang menggunakan Diskresi harus memenuhi syarat sesuai dengan tujuan Diskresi sebagaimana dimaksud dalam Pasal 22 ayat (2) UU Adpem, a. melancarkan penyelenggaraan pemerintahan; b. mengisi kekosongan hukum; c. memberikan kepastian hukum; dan d. mengatasi stagnasi pemerintahan dalam keadaan tertentu guna kemanfaatan dan kepentingan umum.

\section{Tanggung Jawab Pribadi}

Pada perkembangan dewasa ini, diskresi sering dijadikan sebagai alat untuk memperoleh tujuan politiknya, dengan demikian diskresi rentan dengan unsur kepentingan pribadinya. Selaras dengan hal tersebut Ridwan HR menyatakan bahwa terkadang pejabat dalam menggunakan diskresi dipengaruhi oleh berbagai faktor dan kepentingan baik kepentingan sendiri, keluarga, korporasi, maupun kepentingan lainnya sehingga dapat terjadi diskresi yang digunakannya itu menyimpang atau bertentangan dengan norma hukum tertulis. ${ }^{49}$
Tanggung jawab pribadi berkaitan dengan maladministrasi dalam penggunaan wewenang maupun public service. Seorang pejabat yang melaksanakan tugas dan kewenangan jabatan atau membuat kebijakan akan dibebani tanggung jawab pribadi jika ia melakukan tindakan maladministrasi.

Menurut F.R. Bothlingk pejabat atau wakil itu bertanggung jawab sepenuhnya, ketika ia menyalahgunakan situasi dengan melakukan tindakan amoralnya sendiri terhadap kepentingan pihak ketiga ${ }^{50}$ Seseorang bertanggung jawab secara pribadi terhadap pihak ketiga bilamana ia telah bertindak secara moril sangat tercela atau dengan itikad buruk atau dengan sangat ceroboh, yakni melakukan tindakan maladministrasi.

Maladministrasi berasal dari bahasa Latin malum (jahat, buruk, jelek) dan administrare (to manage, mengurus, atau melayani), Maladministrasi berarti pelayanan atau pengurusan yang buruk atau jelak. Berdasarkan Pasal 1 angka (3) Undang-Undang Nomor 37 Tahun 2008 tentang Ombudsman Republik Indonesia, yang dimaksud Maladministrasi adalah Perilaku atau perbuatan melawan hukum, melampaui wewenang, menggunakan wewenang untuk tujuan lain dari yang menjadi tujuan wewenang tersebut, termasuk kelalaian atau pengabaian kewajiban hukum dalam penyelenggaraan pelayanan publik yang dilakukan oleh penyelenggara negara dan pemerintahan yang menimbulkan kerugian materiil dan/atau immaterial bagi masyarakat dan orang perseorangan.

Dalam panduan investigasi untuk Ombudsman Republik Indonesia, disebutkan dua puluh macam maladministrasi, yakni penundaan atas pelayanan (berlarut-larut), tidak menangani, melalaikan kewajiban, persekongkolan, kolusi dan nepotisme, bertindak tidak adil, nyata-nyata berpihak, pemalsuan, pelanggaran undang-undang, perbuatan melawan hukum, di luar kompetensi, tidak kompeten, intervensi, penyimpangan prosedur, 
bertindak sewenang-wenang, penyalahgunaan wewenang, bertindak tidak layak/tidak patut, permintaan imbalan uang/korupsi, penguasaan tanpa hak, dan penggelapan barang bukti. Secara ringkas dapat dikatakan bahwa setiap penyelenggaraan urusan pemerintahan yang didalamnya ada unsur maladministrasi dan merugikan warga Negara, tanggung jawab dan tanggung gugatnya dibebankan kepada pribadi orang yang melakukan tindakan maladministrasi tersebut.

Bentuk tanggung jawab pribadi dalam penggunaan diskresi akibat dari penyalahgunaan wewenangan (detournement de pouvoir) sebagai contoh:

Mantan Menteri Kesehatan Siti Fadilah Supari (2004-2009) yang menjadi terpidana kasus korupsi $^{51}$ terbukti melakukan penyalahgunaan wewenang. Terkait penggunaan diskresi dengan alasan keterbatasan waktu, kejadian luar biasa (KLB) dalam bentuk konsep verbal Menkes/ XI/2005 dan No.15911/Menkes/XI/2005, dengan ini terbitlah surat rekomendasi Permohonan terhadap pengadaan barang dengan penunjukan langsung pembuatan vaksin flu burung, yang menyebabkan negara mengalami kerugian sebesar sekitar Rp 6 miliar. Saat itu Siti Fadilah menyetujui penunjukan langsung pengadaan alat kesehatan dan perbekalan rumah sakit untuk mengatasi wabah flu burung. Selain itu, Siti juga dinilai terbukti menerima suap sebesar Rp 1,9 miliar.

Berdasarkan kasus yang menimpa Siti Fadilah terkait penggunaan diskresi, argumentasi hukum bahwa Siti Fadilah selaku Menteri Kesehatan tidak menjalankan diskresi dengan berpedoman pada AAUPB, bahkan ditambah adanya penyimpangan administrasi atau maladministrasi berupa penyalahgunaan kewenangan (detournement de pouvoir).

Berdasarkan Pasal 17 ayat (2) UU Adpem penyalahgunaan wewenangan mempunyai 3 (tiga) klasifikasi meliputi: 1) larangan melampaui Wewenang; 2) larangan mencampuradukkan
Wewenang; dan/atau 3) larangan bertindak sewenang-wenang. Lebih lanjut, kasus yang menimpa Siti Fadilah mengarah pada kategori larangan melampaui wewenang, yang diafirmasi dengan perbuatan yang bertentangan dengan peraturan perundang-undangan sebagaimana disebutkan dalam Pasal 18 ayat (1) huruf c. Disini Siti Fadilah terbukti telah melakukan tindak pidana korupsi Pasal 3 jo pasal 18 Undang-Undang Nomor 31 Tahun 1999 sebagaimana diubah dengan Undang-Undang Nomor 20 Tahun 2001 tentang Pemberantsan Tindak Pidana Korupsi.

Dalam perkembangannya terjadi perdebatan sengit di antara pakar Hukum Administrasi Negara tatkala ketika peraturan kebijakan pemerintah bisa diujikan oleh pengadilan. Secara historis bermula dari tindakan yang dilakukan Napoleon Bonaparte, sebagaimana dikemukakan Djokosutono berikut ini: $^{52}$

"Seperti kita ketahui, biasanya scheiding van machten maksudnya ialah melindungi yudikatif dari campur tangan eksekutif. Oleh Napoleon hal ini dibalik. Bukan pemerintah jangan turut campur urusan pengadilan tetapi pengadilan jangan turut campur urusan pemerintah. Ini berhubungan dengan pengalamannya sendiri. Tetapi kepada warga negara perseorangan diberi perlindungan. Mereka yang merasa diperlakukan sewenangwenang, dapat memajukan keberatan mereka. Bukan kepada pengadilan, tetapi kepada Conseil d'Etaat."

Terlepas dari bisa tidaknya peraturan kebijakan diuji oleh pengadilan. Dalam hal ini penulis membedakan tanggung jawab jabatan dan tanggung jawab pribadi secara teoritis sebagai berikut:

1. Tanggung jawab jabatan masuk dalam lingkup hukum Administrasi, di karenakan adanya kesalahan yang mengarah pada pelaksanaan administrasi atau prosedural (formil).

\footnotetext{
51 Putusan Mahkamah Agung Nomor 30/PID. Sus/Tpk/2017/PN JKT.PST.

52 Djokosutono, 1982, Kuliah Hukum Tata Negara, Ghalia Indonesia, Jakarta, hlm. 85.
} 
2. Tanggung jawab pribadi masuk dalam lingkup hukum pidana di karenakan berhubungan dengan adanya perbuatan tercela pejabat dalam bentuk perbuatan penyalahgunaan wewenang atau pejabat menggunakan wewenangnya untuk tujuan lain yang menyimpang dari tujuan yang telah diberikan kepada wewenang itu mengarah pada maladministrasi.

Lebih lanjut menurut Tatiek Sri Djamianti mengatakan bahwa dalam konteks Hukum Administrasi, lingkup maladministrasi tidak sematamata terjadi karena perilaku menyimpang. Namun dalam pengertian yang luas dapat terjadi karena ide yang tidak benar atau tidak bagus ataupun tidak bagus pertimbangan tidak rasional. Hal ini terkait dengan kemampuan atau kecakapan pejabat dalam menilai rasionalitas tindakan pemerintahan ataupun membuat keputusan. Beberapa contoh tentang hal tersebut misalnya: 1) gagal dalam mengambil pertimbangan-pertimbangan yang relevan; 2) gagal dalam menjalankan peraturan-peraturan hukum yang ada; 3) gagal dalam meletakan atau menguji prosedur pemerintahan yang ada; dan 4) gagal membuat suatu aturan hukum yang baik atau suatu kebijakan yang baik. ${ }^{53}$ Pada pihak lain, menurut Tatiek Sri Djatmiati mengatakan bahwa dalam konteks tindak pidana korupsi abuse of power (penyalahgunaan wewenang) atau unreasonableness (sewenang-wenang), keduanya merupakan parameter yang utama ada tidaknya penyimpangan. Dalam penggunaan wewenang pemerintahan tentunya di samping asas-asas hukum administrasi yang lain. Dalam hal terdapat unsur maladministrasi dan tentu unsur perbuatan melawan hukum, dan perbuatan itu menjadi tanggung jawab pribadi pejabat yang melakukannya. ${ }^{54}$

Berdasarkan pemaparaan di atas terlihat jelas pembedaan tanggung jawab jabatan dan tanggung jawab pribadi, dilihat dari parameternya yaitu bertentangan dengan asas hukum, peraturan perundang-undangan, perbuatan melawan hukum dan AAUPB. Hal senada dikemukakan Ridwan HR bahwa diskresi dan peraturan kebijakan itu dianggap tidak sah atau menyimpang jika bertentangan dengan peraturan perundang-undangan dan asas hukum (rechtsbeginsel), ada unsur penyalahgunaan wewenang dan unsur sewenang-wenang atau melanggar asas rasionalitas, melanggar hak asasi manusia, bertentangan dengan asas-asas umum pemerintah yang baik dan /atau prinsip penyelenggaraan pemerintahan yang baik (Goed Bestuur), dan terdapat unsur maladministrasi. Sudah barang tentu untuk menguji keabsahan diskresi dan peraturan kebijakan adalah melalui lembaga peradilan..$^{55}$

\section{Penutup}

Diskresi merupakan wewenang bebas, diskresi melekat pada jabatan. Sebagai sesuatu yang melekat pada jabatan, penggunaan diskresi itu pada dasarnya adalah dalam rangka melaksanakan kewenangan jabatan dan public service. Dengan kata lain ketika pejabat pemerintah menggunakan diskresi, ia bertindak untuk dan atas nama jabatan (ambtshalve). Pejabat pemerintah yang menggunakan diskresi, selama tindakan itu dilakukan dalam lingkungan formil wewenangnya (zolang hij tenminste binnen formele kring van zijn bevoegdheid heft gehanded) atau dilakukan dalam rangka melaksanakan kewenangan jabatan, semua konsekuensi yang timbul akan jadi tanggung jawab jabatan. Diskresi sering dijadikan sebagai alat untuk memperoleh tujuan politiknya, dengan demikian diskresi rentan dengan unsur kepentingan pribadinya. Terkadang pejabat dalam menggunakan diskresi dipengaruhi oleh berbagai faktor dan kepentingan baik kepentingan sendiri, keluarga, korporasi, maupun kepentingan lainnya

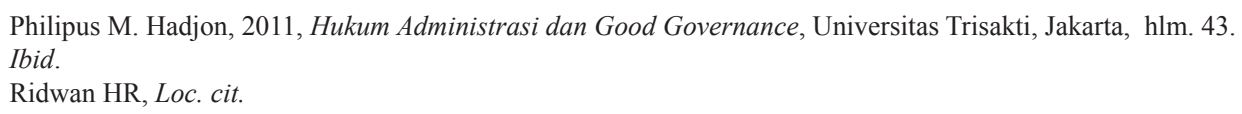


sehingga dapat terjadi diskresi yang digunakannya itu menyimpang atau bertentangan dengan norma hukum. Tanggung jawab pribadi berkaitan dengan maladministrasi dalam penggunaan wewenang maupun public service. Seorang pejabat yang melaksanakan tugas dan kewenangan jabatan atau membuat kebijakan akan dibebani tanggung jawab pribadi jika ia melakukan tindakan maladministrasi.

\section{DAFTAR PUSTAKA}

\section{A. Buku}

Basah, Sjahcran, 2010, Eksistensi dan Tolok Ukur Badan Peradilan Administrasi di Indonesia, Edisi Ke-4, Alumni, Bandung.

Basiang, Martin, 2016, The Contemporray Law Dictionary, Edisi Ke-2, PT Gramedia Pustaka Utama, Jakarta.

Boediono, B, 2003, Pelayanan Prima Perpajakan, Rineka Cipta, Jakarta.

Djokosutono, 1982, Kuliah Hukum Tata Negara, Ghalia Indonesia, Jakarta, 1982.

Dwiyanto, Agus, 2005, Mewujudkan Good

Governance Melalui Pelayanan Publik, UGM Press, Yogyakarta.

Gie, The Liang, 1993, Ensiklopedia Administras, Gunung Agung, Jakarta. , 1993, Keadilan Sebagai Landasan

Bagi Etika Administrasi Pemerintahan dalam Negara Indonesia, Liberty, Yogyakarta.

Hadjon, et al., 2005, Pengantar Hukum Administrasi Indonesia, Introduction to the Indonesian Administrative Law, Edisi Ke-9, Gajah Mada University Press, Yogyakarta.

Hadjon, Philipus M, 2011, Hukum Administrasi dan Good Governance Universitas Trisakti, Jakarta.

Heuken, Adolf, 1987, Kamus Jerman-Indonesia, PT Gramedia, Jakartaa.

HR, Ridwan, 2017, Hukum Administrasi Negara, Edisi Revisi, Rajawali Pers, Jakarta.

Manan, Bagir, 1992, Dasar-Dasar PerundangUndangan Indonesia, IN-HILL-CO, Jakarta. , 1994, Hubungan Antara Pusat dan Daerah Menurut UUD 1945, Sinar Harapan, Jakarta.

Marbun, S.F, et al., 2011. Pokok-Pokok Hukum
Administrasi Negara, Edisi Ke-6, Liberty Press, Yogyakarta.

Muslimin, Amrah, 1985, Beberapa Asas dan Pengertian Pokok Tentang Administrasi dan Hukum Administrasi, Alumni, Bandung.

Ridwan, 2014, Diskresi dan Tanggung Jawab Pemerintah, FH UII Press, Yogyakarta.

Saputra, M. Nata, 1988, Hukum Administrasi Negara, Rajawali, Jakarta.

Sinambela, Lijan Poltak, 2014, Reformasi Pelayanan Publik: Teori, Kebijakan dan Implementasi, Bumi Aksara, Jakarta.

Sipayung, P.J.J, 1989, Pejabat Sebagai Calon Tergugat dalam Peradilan Tata Usaha Negara, Sri Rahayu, Jakarta.

Surayin, 1992, Kamus Lengkap Perancis-Indonesia, Armico, Bandung.

\section{B. Artikel Jurnal}

Mustamu, Julista, "Diskresi dan Tanggung Jawab Administrasi Pemerintahan.”, Jurnal Sasi, Vol. 17, No. 2, April-Juni, 2011.

\section{Makalah}

Marzuki, Laica, "Peraturan Kebijaksanaan (Beleidsregel) Hakikat serta Fungsinya Selaku Sarana Hukum Pemerintahan", Makalah, Penataran Nasional Hukum Acara dan Hukum Administrasi Negara, Fakultas Hukum Universitas Hasanudin, Ujung Pandang, 26-31 Agustus 1996.

\section{Disertasi}

S.F. Marbun, 2001, Pembentukan, Pemberlakuan, dan Peranan Asas-Asas Umum Pemerintahan yang Layak dalam Menjelmakan Peme- 
rintahan yang Baik dan Bersih di Indonesia, Program Doktor Fakultas Hukum Universitas Padjadjaran, Bandung.

\section{E. Internet}

Kamus Besar Bahasa Indonesia (KBBI). "Jabatan," n.d. https://kbbi.web.id/jabatan, https://kbbi. web.id/jabatan, diakses pada 14 Maret 2020.

\section{F. Peraturan Perundang-undangan}

Undang-Undang Dasar Negara Republik Indonesia 1945.

Undang-Undang Nomor 23 Tahun 2014 tentang Pemerintah Daerah (Lembaran Negara Republik Indonesia Tahun 2014 Nomor 244).

Undang-Undang Nomor 25 Tahun 2009 tentang Pelayanan Publik (Lembaran Negara Republik Indonesia Tahun 2009 Nomor 112). Undang-Undang Nomor 30 Tahun 2014 tentang Administrasi Pemerintah (Lembaran Negara
Republik Indonesia Tahun 2014, Nomor 292, Penjelasan Dalam Tambahan Lembaran Negara Republik Indonesia Nomor 5601).

Peraturan Gubernur Provinsi Daerah Khusus Ibukota Jakarta Nomor 187 Tahun 2017 Tentang Tim Gubernur untuk Percepatan Pembangunan (Berita Daerah Provinsi Daerah Khusus Ibukota JAKARTA tahun 2017 Nomor 72109).

Peraturan Presiden Republik Indonesia Nomor 4 Tahun 2015 tentang Perubahan Keempat atas Peraturan Presiden Nomor 54 Tahun 2010 tentang Pengadaan Barang / Jasa Pemerintah (Lembaran Negara Republik Indonesia Tahun 2015 Nomor 5).

\section{G. Putusan}

Putusan Mahkamah Agung Nomor 30/PID. Sus/ Tpk/2017/PN JKT.PST. 